\title{
PRECONDITIONS FOR THE DIFFUSION OF INNOVATIONS IN SOCIAL PEDAGOGICALASSISTANCE IN SCHOOLS
}

\author{
Gražina ŠmitienĖ ${ }^{1}$, Ilona Klanienė² ${ }^{2}$ Donatas LengVinas ${ }^{3}$ \\ Klaipėda University (Lithuania)
}

\begin{abstract}
Innovations in social pedagogical assistance in schools are important for ensuring equal opportunities in education for all social groups, especially for children from disadvantaged social, economic and cultural (SEC) backgrounds, to address the issue of quality and accessible teaching and learning. National school quality reports point to the insufficient implementation and diffusion of innovations in schools. Scientific literature indicates that educators-innovators are important for the diffusion of educational innovations in schools, so they need appropriate conditions created for them to disseminate the innovations in communities. The aim of this research is to identify preconditions for the diffusion of social pedagogical assistance (SPA) innovations in secondary schools. The qualitative research (interviews with social pedagogues) has identified preconditions for the diffusion of SPA innovations in schools: the constant self-reflection of social pedagogues, an enabling (creative) environment, the opportunity to experiment and see the value of innovation, with sufficient time allowed for this collegial support as well as constructive and timely feedback from the school administration.
\end{abstract}

KEY WORDS: social pedagogical assistance, innovation, secondary school.

JEL CODES: 120

DOI: http://dx.doi.org/10.15181/rfds.v34i2.2256

\section{Introduction}

Quality education for each and every minor in the country is the aim, and teachers, child support specialists, education politicians and managers, and parents' associations have combined their efforts to implement it. The provisions for ensuring equal opportunities in education for all social groups, especially children from an unfavourable social, economic and cultural (SEC) environment, are reflected in state documents (Law on Education, 2011; State Education Strategy, 2013-2022). The researchers Bruzgeliavičienė, Brandišauskienè, Česnavičienè and Nedzinskaitè-Mačiūnienė (2020) note that schools 'working with children from an unfavourable SEC context have

1 Gražina Šmitienè - associate professor, doctor of social sciences (educology) in the Department of Pedagogy at Klaipeda University, Faculty of Social and Humanities Sciences

Scientific interests: social education, social pedagogy, social pedagogical assistance

Address: S. Nèries str. 5, LT-92227 Klaipèda

E-mail: g.smitiene@gmail.com

Tel. +37046398624

2 Ilona Klanienè - professor, doctor of social sciences (educology) in the Department of Pedagogy at Klaipeda University, Faculty of Social and Humanities Sciences

Scientific interests: social pedagogy, victimology

Address: S. Nèries str. 5, LT-92227 Klaipeda

E-mail: ijonutyte2@gmail.com

Tel. +370 46398624

3 Donatas Lengvinas - lecturer, doctor of social sciences (educology) in the Department of Pedagogy at Klaipeda University, Faculty of Social and Humanities Sciences

Scientific interests: social pedagogy, resocialisation of children and youth

Address: S. Nèries str. 5, LT-92227 Klaipeda

E-mail: advokatas.lengvinas@gmail.com

Tel. +37046398624 
to put much more effort into ensuring higher achievements by these children'. Support professionals, especially social educators, need to look for new ways and forms of social pedagogical support, in order to increase the social inclusion of SEC groups in schools. This obliges social pedagogues and other support specialists to look for new educational innovations. The highest expectations in implementing the vision of a quality education for all are associated with educational innovations in schools. Innovation and innovative activities are a solution that meets the needs of society better than previous solutions (Drucker, 2006). The concept of innovation in education (and not only in that) is primarily associated with efficiency, improvement in performance, and qualitative change (shift) (Jakubavičius et al., 2008; Bakonis, 2020). Educational innovation is a new idea, tool, product or process introduced into the education system by a person or a group of people, which helps to improve the teaching process (Marsh, Willis, 2007; Baležentis, 2008). According to Jovaiša (2007), innovations in education are related to the concept of novelty, i.e., 'implementation of innovations in teaching, training and upbringing in order to refuse inefficient educational actions' (p. 175). This concept notes the connection between innovation and novelty in activities, and highlights the importance of constant reflection on one's professional activities, the search for more effective educational methods, and involvement in professional activities.

National school research reports on the activities and quality of education note the insufficient rate of the diffusion of educational innovations (Bakonis, 2020; Mikènè, Gailiūtè, 2020; Mikèné, Zaburaitè, 2020; Kalvaitis, 2020). Educational innovations, their content and diversity, have consistently been analysed in domestic and foreign research works of the last decade (Baležentis, 2008; Pečiuliauskienè, 2010; Kvieskiené, Kvieska, 2018; Hatlevik, 2017; Ignatova, 2017, etc). One notable aspect of educational change is the change in the roles of students and teachers, the change in the learning environment, the diversity of teaching and learning resources (Ignatova, 2017). When discussing educational change in schools, Pečiuliauskienė (2010), and Mikène and Zaburaite (2020) discuss the importance of choosing the tools and methods used by teachers in changing students' learning achievements.

An educational paradigm shift in modern schools is changing not only teaching and learning processes but also the psychological environment of the school, creating new educational environments (Monkevičienè et al., 2008). This change is also reflected in the content and means of social pedagogical assistance (Bakonis, 2020). The aim, in the country, is to evaluate schools based on the results achieved, i.e., the obtained qualitative change (shift) of activities, substantiating it with managerial and educational indicators (Bakonis, 2020). On the other hand, it is noted that changes take place too slowly, i.e., some innovations are hard to incorporate into school life. Performance indicators of social pedagogical assistance in secondary schools are no exception. One of the novelties of social pedagogical assistance is bibliotherapy, which, as an educational method, aims at helping students to delve into personal and social problems, and those of learning motivation, to look for solutions (Janavičienè, 2011; Naylor et al., 2010; Carlbring et al., 2011; Moldovan et al., 2013; Pehrsson, McMillen, 2010; Stewart, Ames, 2014; Hazlett-Stevens, Oren, 2017). This method has been discussed in detail in publications on the possibilities of applying bibliotherapy in the activities of social pedagogues, examining the social and pedagogical problems of children and adolescents (Indrašienè, Kapočiūtè, 2009). Although the pedagogical and socio-pedagogical benefits of this method have been proven, this innovation is spreading slowly in the country's educational institutions (Šmitienè, Klanienè, Pavalkytė-Vasiliauskienė, 2019). Schools are encouraged to choose responsibly or create prevention programmes for solving the problems that students face (Olweus 2011; 2018; Gaudiešiūtè, Kavaliauskaitè, 2020), to create inclusive learning and teaching environments (Anderson et al., 2014); therefore, the success of these processes lies not only in the development of social pedagogical innovations, but also in their rapid diffusion in schools. There is still a lack of scientific works in the country that research the diffusion of innovation in social pedagogical assistance in schools.

Research problem: What social pedagogical innovations do social pedagogues implement, and how are they accepted? What are the preconditions for the diffusion of innovations in social pedagogical assistance in secondary schools? The aim of this research is to identify the preconditions for the diffusion of social pedagogical assistance (SPA) innovations in secondary schools.

Research methods: analysis of scientific literature, semi-structured interviews, published (manifest) content analysis. 
1. Theoretical aspects of the diffusion of innovations in social pedagogical assistance in schools

With the expansion of educational environments, and with the increase in the arsenal of educational tools, not only the fact of the occurrence of socio-pedagogical innovations but also their diffusion, become important. According to E. Rogers, the creator of the Diffusion of Innovation Theory (1962), communities adopt innovations with ambiguity. The diffusion of innovations in communities is crucially influenced by the perception of the significance of the innovation, communication channels, time (influencing decision-making and acceptance speed), and social systems in communities (Rogers, 2003). The social context of the implementation of innovation, the specific community of the organisation, as well as the roles, groups and subsystems that have developed in it, become important. In the context of innovations in social pedagogical assistance, the focused cooperation of the socio-pedagogical team and the acceptance of innovations by most members of the community become significant. In defining the social conditions for the diffusion of innovations, Rogers $(1976 ; 2003)$ notes that the innovations brought to the community (group) must guarantee positive change, and be compatible with the existing nature of activities. It is important that their substance is comprehended, leaving freedom of choice (decision) (i.e., to test the innovations in the organisation and get safe feedback). This is usually a complex multicomplex phenomenon, comprising the process, result and technologies (problem-solving methods) (Baležentis, 2008; Jakubavičius et al., 2008). Although the content of the concept of innovations varies, depending on the field where they are applied, the aspect of novelty in the activities of a person or organisation is unambiguously highlighted. Innovations or novelties in professional activities can be: activity ideas and tools (Melnikas et al., 2014; Krušinskas, Benetyte, 2014); the changed result of activities, the new product created (Jakubavičius et al., 2008; Bandzevičiene, 2011); or the introduction of new knowledge in professional activities.

The Diffusion of Innovation Theory (Rogers, 2003) mentions a tipping point that is important for the diffusion of an innovation in an organisation, i.e., when the new idea receives wider recognition and acceptance. The cooperation and communication of the school community, i.e., sharing good practices, appropriate feedback, and psychological and financial support and the like become particularly important. However, the diffusion of innovations always begins with a person, an innovator, who perceives innovations in scientific and practical activities as very important, and who systematically reflects on their work (professional selfreflection, self-analysis) (Jakubavičius et al., 2008). Such employees are usually the bearers (torchbearers) of innovation in organisations. The adoption of innovations in both personal and professional activities, as well as in the organisation, is a step-by-step process. This process follows five stages: knowledge (information about the innovation); persuasion (searching and supplementing the information); the decision (finding the value of the innovation); implementation (episodic application in practice); and confirmation (internal decision on the benefits of the innovation) (Rogers, 2003). When creating an environment conducive to innovation in schools, time costs are emphasised. It is noted that if the educational value of innovation is unquestionably perceived by the school community, especially in the implementation phase, this does not necessarily mean that the innovation will immediately become part of daily activities. This may take time, or the operating conditions should change (Baležentis, 2008). The educational process can adopt technical, technological, pedagogical and management innovations (Janiūnaitè, 2004). Jakubavičius et al. (2008), with respect to the diversity of innovations, identify the following classification groups: content, level of implementation, scope of implementation, novelty, organisational values, performance result, nature, impact of innovations.

The aim of schools to change and improve the educational environment is related not only to the pursuit of academic progress and learning outcomes, but also to the personal progress of students and the improvement of their general (social, emotional) competencies. It has been ascertained that the improvement in the quality of teachers' work (changing educational methods, faster inclusion of educational innovations) results in changing relations among students, and an increased ability to resolve mutual conflicts and greater tolerance (Mikèné, Gailiūte, 2020). The arsenal of social pedagogical assistance tools is constantly being updated and supplemented with new social pedagogical assistance tools and social education methods. The Description of the Procedure on Providing Social Pedagogical Assistance to Children and Pupils of 2016 
(02/11/2016, No V-950LR) provides for the introduction of innovation at the national level, school mediation, which must be implemented by social pedagogues. Recently, different methods and tools for social education and social pedagogical prevention have emerged in social pedagogical practice (Bakonis, 2020), schools must implement at least one prevention programme; therefore, social pedagogues and school communities are constantly looking for innovations. The latest school activity reports have recorded an increase in the participation of teachers and childcare professionals in various competence development events, with the aim of introducing pedagogues to educational innovations and encouraging them to apply them in their activities, but no breakthrough has been reached (Bakonis, 2020). National evaluation reports on the state of education show the insufficient pace of innovation. School management processes are investigated for possible reasons. As Mikènè and Zaburaite (2020) observe, the leadership and management area is the least improved area in secondary schools. In this area, the usual choice is to improve cooperation with parents rather than to encourage the school community to incorporate innovations (Mikèné, Zaburaite, 2020).

As Kalvaitis (2020) notes, qualitative change (shift) in the educational culture in schools is associated with the higher professional qualification of the teachers, and the qualitative improvement of competence, creating conditions for the diffusion of innovations in schools. The development of these conditions is especially relevant in schools where the majority of students come from disadvantaged social, economic and cultural backgrounds (SEC). In these schools, the quality of teachers' professional competence, and the ability to incorporate educational innovations into their activities, become essential elements in ensuring equal learning opportunities for all students, and reducing the gap in students' academic progress among learners from different social groups.

\section{Research methodology}

In order to reveal aspects of the diffusion of innovations of social pedagogical assistance in secondary schools, qualitative research was conducted. The qualitative content analysis and structured interview method were chosen. This research method allowed for the identification of the attitude of social pedagogues to innovations in socio-pedagogical activities, the choice of new methods, means and forms of social pedagogical assistance, and the diffusion of these innovations in schools. The criterion sampling method was applied in the research, which allowed for the selection of informants based on characteristics important in revealing the research problem. The research involved social pedagogues with at least ten years of work experience in secondary schools. There were 29 social pedagogues invited to participate in the research. To reveal the research problem, interviews were conducted with nine social pedagogues who work in different secondary schools, who stated that they have been adopting social pedagogical assistance innovations in their work and systematically reflecting on their activities, and have been actively getting involved in school community life. These social pedagogues completed an MA in social pedagogy; therefore, their approach to innovations in social pedagogical assistance can be considered competent. All the social pedagogues who participated in the study were women. The following topics (questions) for informants were selected for the structured interview: innovations in social pedagogical assistance; conditions for the emergence of innovations in social pedagogical assistance; and conditions for the diffusion of innovations in social pedagogical assistance in schools.

In order to ensure the ethics of the research, consent was obtained from all the research participants to take part, interviews were recorded and the recordings were later transcribed; and the information was encoded (social pedagogues, SP). The data collected through the interview method was then analysed to segregate subcategories and categories. The research results were processed using the method of manifest content analysis. The research results were interpreted and based on pooled data and textual evidence. This enabled us to interpret and make conclusions based on the analysed text (Žydžiūnaitè, Sabaliauskas, 2017).

\section{Research results}

The research participants were asked how they understood social pedagogical innovations in their activities. The following subcategories were identified in this category: the form of social pedagogical assistance, 
social pedagogical methods, technological tools, changed approach to professional activities. As has been noted in the theoretical part, innovations in professional activities are related to the result and technologies. The subcategories identified in this category illustrate this (presented in Figure 1). All the pedagogues who participated in the research stated that they are constantly adopting innovations in their activities, i.e., to discover or develop new ways of working, and to look for new ways of finding solutions to social pedagogical problems in schools: '...I see all innovations positively, because without them, I think our work would be much more complicated, and it would become routine...' (SP1); 'Innovation or novelties are an integral part of my work, because situations and circumstances in schools change...' (SP9). By analysing the informants' reflections on innovations in their activities, it was observed that attentive self-reflection is a constant companion in their professional activities; therefore, the innovations discovered or developed in professional activities change not only individual practices of activities, but also often the direction of professional activities. In the singled-out subcategory changed approach professional activities, informants mention: ' $I$ had to rethink what, as a social pedagogue, I do in school' (SP7); 'One does not want to stew in one's own juice' (SP1); 'I work with children, they change, and so do my activities' (SP8). Thus, the changed approach to their activities in schools and emerging new contexts of social pedagogical problems encourage social pedagogues to look for new forms of activities. In the subcategory forms of activities, informants revealed that, in addition to the usual forms of group and individual work, with the new needs of distance learning arising, new forms of activities need to be mastered and incorporated too: 'The situations that have evolved, the topics and problems mentioned more often during the conversations with community members, prompted to look for some forms of delivering information, talking' (SP2); 'Social counselling virtually as the education process has been moved to the digital space' (SP5). When changing forms of activities or improving existing ones, pedagogues must look for new methods of assistance (SPA), or incorporate the most interesting ones into the activities: 'Just when I saw that method, it really caught my attention, and later I saw what a great result it gave' (SP8). In the subcategory methods of social pedagogical assistance (SPA), informants revealed that with new methods they usually seek to avoid the monotony of education, or to escape routine in their activities, and broaden the methodological arsenal of their activities: 'The more I know, the more flexibility I have at work' (SP1). The research participants listed the following innovations mastered and presented in school communities over the last few years: bibliography, photo collage, Forum theatre method, mediation, Family conference, various programmes for social skills and bullying prevention, etc. It should be noted that informants apply information and communication technologies in their activities to a wide extent. When talking about the new technologies emerging in their work, they do not emphasise them as important innovations, because the educational situation today (distance learning) dictates its own conditions: 'well, what else is there to do (...) after all, we need to find a way...' (SP5). The application of technological innovations in their work to a wider and bolder extent is more often hindered by the financial issue: 'It would be nice, but only when you checked it was free' (SP7), or the question of the equipment available: 'the fact that my computer doesn't support' (SP9). In the subcategory technological tools of social pedagogical assistance (SPA), the informants note that: "new information technologies had to be used, which helped to keep in contact with the students and communicate successfully' (SP4); 'Currently, I could identify consulting on various distance learning platforms (Zoom, Teams, Messenger) as a novelty and innovation' (SP3). The need to consult and communicate with students in the situation of distance learning encouraged social pedagogues to master these communication environments. The distance learning encouraged some of them to move communication with the students and their parents to social situation networks: 'Making use of social networks: there are some important things written on Facebook pages that help understand the current situation' (SP2). 


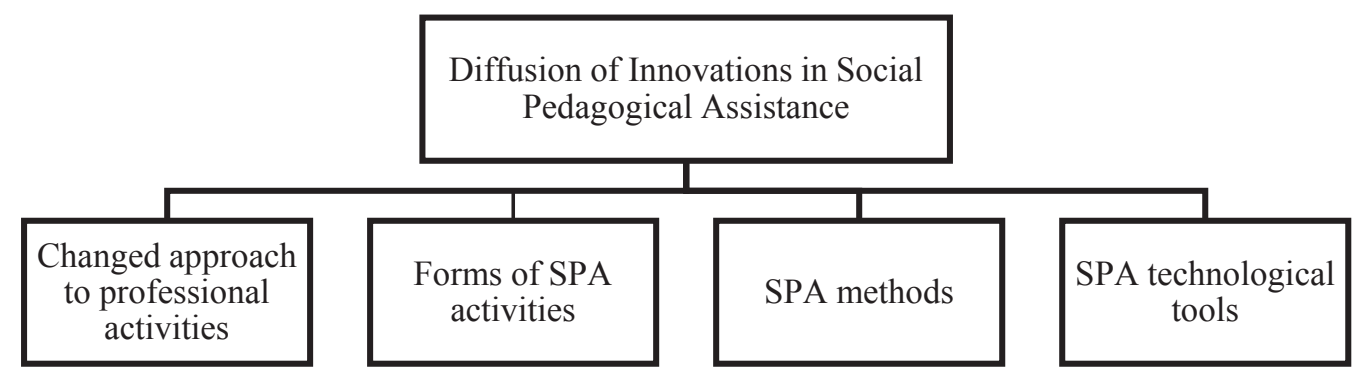

Figure 1. Informants' opinions on the diffusion of innovations in social pedagogical assistance in schools

Source: author's construction based on research.

It should be noted that the stories of the research participants about the diffusion of innovations in social pedagogical assistance in schools identified the main stages in the diffusion of innovations: knowledge of information about the innovation, i.e., how and where social pedagogues learnt about the innovation ('sharing with each other in methodological circles' [SP1]; 'I've learned more from courses, collegial experience, and on the Internet [SP6]); the decision, i.e., to assess the value of the innovation or novelty to their work ('it's not enough just to read it, one must try it' (SP8); implementation, i.e., the transfer of innovation to one's professional activities, time allocated for this: 'it's already two years that I have been trying' (SP7); confirmation ('I have noticed that it is gradually getting easier to prepare for the meetings' (SP2); 'we tried, and there were like-minded people who supported it, and the students liked it' (SP3). The experiences associated with the search for innovations in social pedagogical assistance are very different, but the statements of informants feature a unanimous desire to search for more effective ways of assistance, i.e., to solve social pedagogical problems in a quality manner. This encourages social pedagogues to be open to information, to hear and notice educational innovations that can help address them. We can describe the research participants as social pedagogues-innovators who are open to innovations, and who deem important not only high-quality social pedagogical assistance in schools, but also the diffusion of innovations in social pedagogical assistance throughout communities: '...little by little, I continue delivering that message to the community' (SP2); 'I want to talk about it, to share' (SP2); 'it would be interesting to learn what working methods the scientists are proposing to test, how their proposed methods would work in our community' (SP3).

The analysis of informants' statements about preconditions for the diffusion of innovations in social pedagogical assistance (SPA) in schools has identified the following categories: an enabling (creative) environment, self-reflection, confirmed expectations, collegial support, and freedom of choice (decision) (Figure 2).

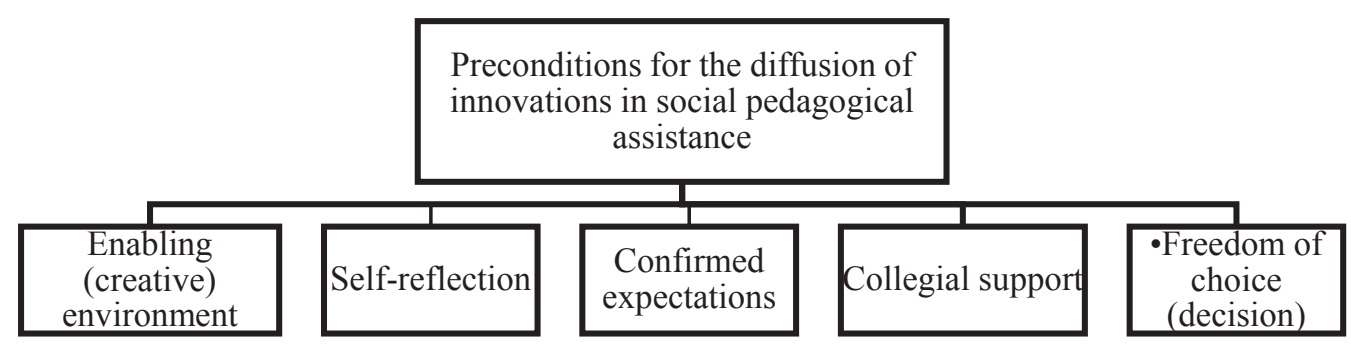

Figure 2. Informants' opinions of the diffusion of innovations in social pedagogical assistance

Source: author's construction based on research. 
In the subcategory self-reflection, the informants revealed that the starting point for the search for new work methods, forms and technologies is the result of their professional activities, i.e., naming the existing gaps and inefficiencies in the work: 'after a routine period looking for the pros and cons at work, I started looking for new ways'(SP1); 'I have found for myself' (SP8). It should be noted that the subcategory an enabling (creative) environment reflects the determination of social pedagogues not only to find a suitable educational innovation and include it in their activities, but also the determination to interpret the innovation or create in their own way: 'Currently, I notice that the number of students who may possibly have special needs is growing in our gymnasium, only that they have not been identified' (SP3); 'It is important for me to understand a new thing so that I can adapt, change it'(SP6); 'I have heard information about it, but I had to understand it myself to accept' (SP8). On the other hand, the informants note that it is very important to understand the meaningfulness of their activities in the face of failures during the implementation of innovations in schools: 'one only needs not to get disappointed in themselves' (SP7). In the subcategory confirmed expectations, the informants reveal that the decision regarding the suitability of innovation is made only after making sure the expectations related to the innovation have been validated. This confirmation is based not only on one's own experience, concrete result, but also on how the innovation is accepted by the students, colleagues: 'I tried it first, made sure the students liked it, and that it was giving the result, then I started sharing it with colleagues' (SP7); 'We do try a number of new methods, but for various reasons, the new methods do not give the desired results or are difficult to implement. That is why we use those that attract students and give visible results' (SP3). The research data reveal that social pedagogues critically analyse innovations in their professional activities, and the quality result of the implemented innovation is important to them. The concept of quality was especially common in the narratives presented, which testifies to the intention of social pedagogues to focus on qualitative rather than quantitative performance criteria in their activities. As the stories told by informants have proven, it is not personal preconditions but also the approach of the school community and its administration to innovation that play an important role in the diffusion of SPA innovations in schools. Both internal motives and external support are important for their decision to incorporate an element of innovation in their work. In the subcategory collegial support, informants emphasise both the support coming from colleagues (teachers, class teachers, child support specialists), their interest in innovation, joint activities, and psychological and managerial support coming from school leaders: 'you feel collegial support and do things with more courage' (SP7); 'the director understood and supported me a lot' (SP1); '...I got a day off' (SP6). On one hand, social pedagogues mention that their own internal decision about the value of the innovation is paramount. On the other hand, reflecting on the speed and scale of innovation, they recognise that the support of the school community and readiness to accept the innovation are very important: 'I feel very frustrated when colleagues are not interested' (SP2); 'it is important when the administration shows support'(SP2). In the subcategory freedom of (choice) decision, informants note the importance of time in selecting, testing and adapting innovations in their activities, the opportunity for selfdetermination, and the need for timely feedback from the administration: 'it is excellent if you can try without haste, evaluating...' (SP6); 'I believe that only one can decide for oneself whether an innovation is suitable to them' (SP9); 'If you are constantly trapped in a routine and just run, there is no time left' for innovations (SP7); 'External "here and now" requirements are very disturbing' (SP1).

Having summarised the results of research, it was noted that the social pedagogues who participated in the research were of the opinion that the implementation of SPA innovations in secondary schools is one of the guarantors of quality social pedagogical assistance. The social pedagogues who participated in the research can be referred to as innovators who are open to innovation, actively cooperate in professional networks and school communities, and systematically improve professional competencies, even after postgraduate studies in social pedagogy. As social pedagogical assistance, the informants also named the changed attitude towards one's professional activities, the development of new forms of activities, and the discovery of new methods and means of social pedagogical assistance. Based on the analysis performed, the essential preconditions for the diffusion of innovation in social pedagogical assistance in schools include: continuous professional self-reflection, an enabling (creative) environment in schools, the discovered personal value of innovation (justified expectations), support from managers and colleagues, and freedom to choose and adopt innovations. 


\section{Conclusions}

A qualitative change (shift) in social pedagogical assistance in schools is an essential condition for quality education for every student. Social pedagogical innovations are implemented in the country's schools in order to guarantee equal rights and opportunities for every citizen in the country to a comprehensive education and training, to develop their self-expression, and to encourage social inclusion. Particularly vulnerable in this context are children that live in unfavourable social, economic and cultural environments, so pedagogues and assistance professionals are constantly looking for innovations in social pedagogical assistance, and carry out their diffusion.

The results of the research have revealed that social pedagogues are innovators who actively incorporate educational innovation, both in their professional activities and their diffusion in school communities. Most social pedagogues associate innovations in their activities with both an increase in pedagogical interaction and with the aim to employ quality solutions to emerging social pedagogical problems, to choose more advanced methods of social pedagogical prevention. It should be noted that social pedagogues are usually innovators in their communities, who select, test and disseminate information about innovations in social pedagogical assistance themselves.

The results of the research reveal the preconditions for the diffusion of innovations in social pedagogical assistance in schools: continuous self-reflection, an enabling (creative) environment, the opportunity to try and see the value of innovation, sufficient time allocated, collegial support, and constructive and timely feedback from the administration.

\section{References}

Anderson, J., Boyle, Ch., Deppeler, J. (2014). The Ecology of Inclusive Education: Reconceptualising Bronfenbrenner. Equality and Inclusion. Netherlands: Sense Publisher.

Bakonis, E. (2020). Švietimo ịstaigu vadovu veiklos vertinimo ataskaitos. Analizès ataskaita. Nacionalinė švietimo agentūra. Vilnius. Prieiga internete: https://www.nsa.smm.lt/wp-content/uploads/2020/01/Svietimo-istaigos-vadovu-ataskaitos_analize_Internetinis.pdf [žiūrèta 2021-03-26].

Baležentis, A. (2008). Inovatyviųų mokymo formų ir metodų taikymo galimybės žmogiškujų išteklių vadyboje. Viešoji politika ir administravimas, Nr. 26, p. 97-104.

Bandzevičiene, R. (2011). Inovacijų vadybos psichologija. Kaunas: Smaltija.

Bruzgeliavičienė, R., Brandišauskienė, A., Česnavičienė, J., Nedzinskaitė-Mačiūnienė, R. (2020). Kokybiškas švietimas visiems visa gyvenima: artejjame prie vizijos ar tolstame nuo jos. Nacionaliné švietimo agentūra. Prieiga internete: https://www.smm.lt/uploads/documents/tyrimai_ir_analizes/2020/Kokybi\%C5\%A1kas\%20\%C5\%A1vietimas\%20 visiems\%20(2020).pdf [žiūrèta 2021-01-05].

Carlbring, P., Maurin, T., Sjomark, J., Maurin, L., Westling, B. E., Ekselius, L., Cuijpers, P., Andersson, G. (2011). All at once or one at a time? A randomized controlled trial comparing two ways to deliver bibliotherapy for panic disorder. Cognitive Behaviour Therapy, Vol. 40 (3), p. 228-235.

Drucker, P. F. (2006). Innovation and Entrepreneurship. New York: Harper\&Row.

Gaudiešiūte, E., Kavaliauskaitè, D. (2020). Vaiku ir paaugliu psichikos sunkumai ir pagalbos galimybès mokyklose. Lietuvos situacijos analize. Prieiga internete: http://kurklt.lt/wp-content/uploads/2020/03/Esamos-situacijosanaliz\%C4\%97.pdf [žiūrèta 2021-02-10].

Gulbinas, R., Rapkauskaitė, G. (2015). Elektroninių žaidimu socioedukacinis vertinimas. Prieiga internete: https:/etalpykla.lituanistikadb.lt/object/LT-LDB0001:J.04 2015 1497255393388/J.04 2015 1497255393388.pdf [Žiūrèta 2021-03-09].

Hatlevik, E. (2017). Examining the Relationship between Teachers' Self-Efficacy, their Digital Competence, Strategies to Evaluate Information, and use of ICT at School. Scandinavian Journal of Educational Research, Vol. 61(5), p. 555-567.

Hazlett-Stevens H., Oren Y. (2017). Effectiveness of mindfulness-based stress reduction bibliotherapy: a preliminaryy randomized controlled trial. Journal of Clinical Psychology, Vol. 73(6), p. 626-637.

Ignatova, N. (2017). Informacinemis ir komunikacinèmis technologijomis gristo mokymo(si) personalizavimo veiksmingumas pradineje ir pagrindinëje mokykloje. Prieiga internete: https://www.vdu.lt/cris/bitstream/20.500.12259/115582/1/natalija_ignatova_dd.pdf [žiūrẻta 2021-03-09].

Indrašienė, V., Kapočiūtè, E. (2009). Biblioterapijos elementų taikymas, sprendžiant paauglių socialines ir pedagogines problemas. Socialinis ugdymas, Nr. 7(18), p. 19-29. 
Jakubavičius, A., Jucevičius, A., Jucevičius, R., Kriaučionienė, M., Keršys, M. (2008). Inovacijos versle: procesai, parama, tinklaveika. Vilnius: Lietuvos inovacijų centras.

Janavičienè, D. (2011). Biblioterapijos paslaugų poreikis Lietuvos viešosiose bibliotekose. Knygotyra, Nr. 57, p. $207-225$.

Janiūnaitė, B. (2004). Edukacinés novacijos ir jų diegimas. Kaunas: Technologija.

Jovaiša, L. (2007). Enciklopedinis edukologijos žodynas. Vilnius: Gimtasis žodis.

Kalvaitis, A. (2020). Švietimo kokybę gerinantys modernios pamokos aspektai Lietuvos bendrojo ugdymo mokyklose. Analize. NŠA. Prieiga internete: https://www.nsa.smm.lt/wp-content/uploads/2020/06/Svietimo-kokybe-gerinantys-aspektai_analize_elektroninis.pdf [žiūrèta 2021-03-10].

Krušinskas, R., Benetytè, R. (2014). Inovacijos įmonès veiklos kontekste: teorinis aspektas. Apskaitos ir finansų mokslas ir studijos: problemos ir perspektyvos. Doi:10.15544/SSAF.2014.08 [žiūrèta 2021-02-03].

Kvieskienė, G., Kvieska, V. (2018). Personalizuoto ugdymosi inovacijos ir sumanioji komunikacija. Prieiga internete: http://socialinisugdymas.leu.lt/index.php/socialinisugdymas/article/view/224/207 [žiūrèta 2021-03-09].

Lietuvos Respublikos Seimo 2013 m. gruodžio 23 d. nutarimas Nr. XII-745 „Dèl valstybinès švietimo $2013-2022$ metu strategijos patvirtinimo“. (2013). Prieiga internete: https://e-seimas.lrs.lt/portal/legalAct/lt/TAD/TAIS.463390 [žiūrèta 2021-01-29].

Lietuvos Respublikos švietimo ir mokslo ministro $2016 \mathrm{~m}$. lapkričio 2 d. įsakymas Nr. V-950 Socialinès pedagoginès pagalbos teikimo vaikui ir mokiniui tvarkos aprašas. (2016). Prieiga internete: https://e-seimas.lrs.lt/portal/legalAct/lt/ TAD/06ad87e0a20911e68987e8320e9a5185 [žiūrèta 2021-01-29].

Lietuvos Respublikos Švietimo įstatymas, įstatymo pakeitimo ịstatymas. (2011). Nr. XI-1281. Prieiga interente: https://eseimas.lrs.lt/portal/legalAct/lt/TAD/TAIS.395105/asr [žiūrèta 2021-01-29].

Marsh, C. J., Willis, G. (2007). Curriculum: Alternative approaches, ongoing issues. Upper Saddle River. New Jersey: Pearson Prentice.

Melnikas, B., Jakubavičius, A., Strazdas, R., Chlivickas, E., Lobanova, L., Stankevičienė, J. (2014). Intelektinis verslas. Vilnius: Technika.

Mikènè, S., Zaburaitè, G. (2020). Pagrindinio ugdymo mokiniu socialinès-pilietinès ir pažintinès kultūrinès veiklos organizavimas bendrojo ugdymo mokyklose. Tyrimo ataskaita. Vilnius: NŠA. Prieiga internete: https://www.nsa. smm.lt/wp-content/uploads/2020/05/Veiklos-organizavimas_tyrimo-ataskaita_Mikene_internetinis.pdf [žiūrèta 2021-01-29].

Mikènè, S., Gailiūtè, E. (2020). Pažangos samprata mokyklose (pagal mokyklu ìsivertinimo duomenis). Tyrimo ataskaita. Prieiga internete: https://www.nsa.smm.lt/wp-content/uploads/2020/07/Pazangos-samprata-mokyklose. pdf [žiūrèta 2021-02-03].

Moldovan, R., Cobeanu, O., David, D. (2013). Cognitive bibliotherapy for mild depressive symptomatology: randomized clinical trial of efficacy and mechanisms of change. Clinical Psychology and Psychotherapy, Vol. 20, p. 482-493.

Monkevičienė, O., Glebuvienė, V. S., Jonilienė, M., Montvilaitė. S., Stankevičienė, K., Mauragienė, V., Tarasonienė, A. L. (2008). Mokslinio tyrimo ikimokyklinio ugdymo ịvairové: esama situacija ir visuomenès lūkesčiai. Galutine moksline ataskaita. Prieiga internete: https://www.smm.lt/uploads/documents/ kiti/VPU-atask-paslaug-ivairove.pdf [žiūrèta 2021-03 15].

Naylor, E. V., Antonuccio, D. O., Litt, M., Johnson, G. E., Spogen, D. R., Williams, R., McCarthy, C., Lu, M. M., Fiore, D. C., Higgins, D. L. (2010). Bibliotherapy as a treatment for depression in primary care. Journal of Clinical Psychology Medicine Settings, Vol. 17, p. 258-271.

Olweus, D. (2011). Patyčios mokykloje. Ka žinome ir ka galime padaryti. Vilnius: Alma littera.

Olweus, D., Limber, S. P., Flerx, V. C., Mullin N., Riese, J., Snyder, M., Thyholdt, R., Baraldsnes, A. (2018). Olweus patyčiu prevencijos programa. Igyvendinimo mokykloje vadovas. Kaunas: Vitae Litera.

Pečiuliauskienè, P. (2010), Judejjimo reiškinio nagrinèjimo tarpdalykinės prielaidos pagrindinės mokyklos gamtamoksliniuose vadovėliuose ir edukacinèje praktikoje. Pedagogika, Nr. 99, p. 77-82.

Pehrsson, D. E., McMillen, P. S. (2010). A national survey of bibliotherapy preparation and practices of professional counselors. Journal of Creativity in Mental Health, Vol. 5, p. 412-425.

Rogers, E. M. (1976). Communication and development: The passing of the dominant paradigm. Communication Research, Vol. 3(2), p. 213-240.

Rogers, E. M. (2003). Diffusion of innovations. New York, NY: Free Press.

Stewart, P. A., Ames, G. P. (2014). Using culturally affirming, thematically appropriate bibliotherapy to cope with trauma. Journal of Child \& Adolescent Trauma, Vol. 7, p. 227-236.

Šmitienè, G., Klanienè, I., Pavalkyte-Vasiliauskienė, G. (2020). Socio-Pedagogical Aspects of the Application of Bibliotherapy at Day Center. Region Formation and Development Studies, Vol. 31, No. 2, p. 81-90.

Žydžiūnaitè, V., Sabaliauskas, S. (2017). Kokybiniai tyrimai. Principai ir metodai: vadovèlis socialiniu mokslu studiju programu studentams. Vilnius: Vaga. 


\title{
SOCIALINÉS PEDAGOGINÉS PAGALBOS INOVACIJU SKLAIDOS PRIELAIDOS MOKYKLOJE
}

\author{
Gražina Šmitienè, Ilona Klaniené, Donatas Lengvinas \\ Klaipėdos universitetas (Lietuva)
}

\section{Santrauka}

Socialinès pedagoginès pagalbos inovacijos yra svarbios, siekiant užtikrinti lygias švietimo galimybes visoms visuomenès grupèms, ypač vaikams iš nepalankios socialinès, ekonominès, kultūrinès (SEK) aplinkos, taip sprendžiant kokybiško ir prieinamo mokymo(si) problemą. Nepakankamą inovacijų pažangą mokyklose liudija nacionalinès veiklos kokybès ataskaitos. Mokslinėje literatūroje pažymima, kad švietimo inovacijų sklaidą mokyklose užtikrina pedagogai novatoriai, svarbu sudaryti tinkamas inovacijų sklaidos bendruomenėse sąlygas. Šio tyrimo tikslas - atskleisti socialinės pedagoginės pagalbos inovacijų sklaidos prielaidas bendrojo ugdymo mokykloje. Atlikus kokybinį tyrimą (socialinių pedagogų) atskleistos SPP inovacijų sklaidos prielaidos mokykloje: nuolatinè socialinių pedagogų veiklos savirefleksija, kurti igalinanti aplinka, galimybe bandyti ir įsitikinti inovacijos vertingumu, tam skiriama pakankamai laiko, yra kolegų palaikymas ir konstruktyvus bei savalaikiškas administracijos grįžtamasis ryšys.

Siekiant atskleisti socialinės pedagoginès pagalbos inovacijų sklaidos aspektus bendrojo ugdymo mokykloje, atliktas kokybinis tyrimas. Pasirinkta kokybinè turinio analizè, struktūruoto interviu metodas. Pastarasis metodas leido išsiaiškinti socialinių pedagogų požiūrị ị socialinès pedagoginès veiklos inovacijas, pasirenkamus naujus socialinès pedagoginès pagalbos metodus, priemones, formas. Tyrimui atlikti taikyta kritinė atranka, leidusi atrinkti informatorius pagal tam tikras savybes. Tyrime dalyvavo socialiniai pedagogai, kurių darbo stažas bendrojo ugdymo mokykloje - ne mažesnis kaip 10 metų. Dalyvauti pakviesti 29 socialiniai pedagogai. Tyrimo problemai atskleisti pasirinkti pokalbiai su 9 socialiniais pedagogais, dirbančiais skirtingose bendrojo ugdymo mokyklose ir teigiančiais, kad savo darbe taiko socialinès pedagoginès pagalbos inovacijas, sistemingai reflektuoja savo veiklą, aktyviai dalyvauja mokyklos bendruomenės gyvenime. Šie socialiniai pedagogai yra baigę socialinès pedagogikos magistrantūros studijas, tad jų požiūris i socialinès pedagoginès pagalbos inovacijas laikytinas kompetentingu. Struktūruotam interviu pasirinktos šios temos (klausimai) informantams: inovacijos teikiant socialinę pedagoginę pagalbą; jų atsiradimo sąlygos; socialinès pedagoginės pagalbos inovacijų sklaidos mokykloje sąlygos.

Apibendrinus tyrimo rezultatus pažymèta, kad, tyrime dalyvavusių socialinių pedagogiu nuomone, SPP inovacijų diegimas bendrojo ugdymo mokykloje yra vienas socialinès pedagoginès pagalbos kokybės garantijų. Tyrime dalyvavusias socialines pedagoges galima apibūdinti kaip novatores, kurios yra atviros naujovèms, aktyviai bendradarbiauja profesiniuose tinkluose ir mokyklų bendruomenių veikloje, sistemingai tobulina profesines kompetencijas pagal atitinkamas universiteto programas. Kaip socialinès pedagoginès pagalbos inovacijas informantès ịvardija ir požiūrio ị profesinę veiklą kaitą, kuriamas naujas veiklos formas, atrandamus naujus socialinès pedagoginès pagalbos metodus bei priemones. Remiantis atliktos analizès duomenimis, esminès socialinès pedagoginès pagalbos inovacijų sklaidos mokykloje prielaidos yra: nuolatinė profesinè savirefleksija, kūrybai ịgalinanti mokyklos aplinka, atrasta inovacijos asmeninė vertè (pasiteisinę lūkesčiai), vadovų ir kolegų palaikymas, laisvẻ apsispręsti dèl inovacijų pasirinkimo ir taikymo.

PAGRINDINIAI ŽODŽIAI: socialinè pedagoginè pagalba, inovacijos, bendrojo ugdymo mokykla.

JEL KLASIFIKACIJA: I20.

Received: 2021-03-06

Revised: 2021-04-28

Accepted: 2021-05-04 